\title{
Intraoperative frozen section assessment in the evaluation of axillary sentinel lymph node in breast cancer
}

Primeira submissão em 02/03/12 Última submissão em 05/03/12 Aceito para publicação em 11/07/12 Publicado em 20/10/12

\section{Exame intraoperatório por congelação na avaliação do linfonodo sentinela axilar no câncer de mama}

Jorge Alberto Thomé1; Carlos Fabián Mendiburu2; Fabio Marcondes C. Palma ${ }^{3}$; Antonio R. Moriel'; Agnes Cristina Fett-Conte ${ }^{5}$

\section{key words}

Intraoperative frozen

section analysis

Metastases

Axillary sentinel lymph

nodes

Breast cancer

\section{abstract}

Introduction: Intraoperative frozen section analysis has become a routine procedure to evaluate the status of axillary sentinel lymph nodes in breast cancer. Objectives: To evaluate the accuracy and sensitivity of FS in the detection of metastases in axillary sentinel lymph nodes and to investigate the predictive value of variables such as patients' age, tumor staging, histology, grade, and estrogen receptor expression. Material and Methods: We analyzed retrospectively the results of $177 \mathrm{FS}$ procedures. The patients' age and tumor characteristics were organized in a database and the association with the presence of metastases was analyzed. Results: Metastases were detected in 22 cases (12\%). All macrometastases and one micrometastasis were detected by FS. Additional micrometastases were detected in post-operative analysis, from which five were determined by hematoxylin and eosin staining (H\&E) and three by immunohistochemistry (IHC). FS diagnosis data proved to have an overall accuracy of $95 \%$, sensitivity of $64 \%$, and specificity of $100 \%$. None of the analyzed variables showed significant association with lymph node metastases. Conclusion: Our results show that intraoperative $\mathrm{FS}$ is a highly accurate and sensitive method to detect macrometastases. However, it is inaccurate in the detection of micrometastases. The use of IHC improves the detection of micrometastases in postoperative analyses. The patient's age and tumor characteristics such as staging, histology, grade and estrogen receptor expression have low predictive value for lymph node metastasis in breast cancer.

\footnotetext{
Introdução: O exame intraoperatório por congelação tornou-se um procedimento de rotina na avaliação do linfonodo sentinela axilar no câncer de mama. Objetivos: Avaliar a acurácia e a sensibilidade do FS na detecção de metástases em linfonodo sentinela axilar e investigar o valor preditivo para metástases de variáveis, como idade dos pacientes, estadiamento, tipo histológico, grau e expressão do receptor de estrogênio do tumor. Material e métodos: Foram analisados, retrospectivamente, os resultados de 177 procedimentos de congelação. A idade dos pacientes e as características dos tumores foram organizadas em um banco de dados e a relação com a presença de metástases foi analisada. Resultados: Foram detectadas metástases em 22 (12\%) casos. Todas as macrometastases e uma micrometastases foram detectadas pelo método de congelação. Micrometastases adicionais foram identificadas nas análises pós-operatórias, cinco por coloração com hematoxilina e eosina (H\&E) e três por imuno-histoquímica. O método de congelação mostrou acurácia geral de $95 \%$, sensibilidade de $64 \%$ e especificidade de 100\%. Nenhuma associação significativa foi observada entre a presença de metástases e as variáveis analisadas. Conclusão: Nossos resultados mostram que o exame por congelação possui acurácia e sensibilidade elevadas para a detecção de macrometastases; no entanto, é pouco eficiente na identificação de micrometastases. O uso de imuno-histoquímica melhora a detecção de metástases na análise pós-operatória. A idade do paciente e as características do tumor, como estadiamento, tipo histológico, grau e a expressão do receptor de estrogênio têm de valor preditivo baixo para metástases nodais em câncer de mama.
}

\footnotetext{
1. Department of Pathology, São José do Rio Preto Medical School, São José do Rio Preto, SP, Brazil.

2. Department of Immunohistochemistry, Institute of Pathology and Cytopathology, São José do Rio Preto, SP, Brazil.

3. Department of Pathology, Institute of Pathology and Cytopathology, São José do Rio Preto, SP, Brazil.

4. Department of Cytopathology, Institute of Pathology and Cytopathology, São José do Rio Preto, SP, Brazil.

5. Department of Molecular Biology, São José do Rio Preto Medical School, São José do Rio Preto, SP, Brazil.
}

unitermos

Exame por congelação

Metástases

Linfonodo axilar

Câncer de mama 


\section{Introduction}

The status of axillary lymph nodes is one of the most powerful prognostic factors predicting the recurrence and long-term survival in breast cancer patients, and significantly affects adjuvant therapy decisions ${ }^{(13)}$. The intra-operative frozen section (FS) diagnosis of SLN biopsy has become routine practice in the surgical therapy of breast cancer patients. Its purpose is to identify those patients who will benefit from immediate axillary lymph node dissection (ALND) and who will, thus, be spared the expense, inconvenience, and emotional turmoil of a second operation. Therefore, FS must be very sensitive to detect at least macrometastases and be specific to avoid performing an unnecessary ALND(5). The correlation of intra-operative FS analysis with the final histopathologic diagnosis on permanent section should form an integral part of quality activities in the surgical pathology laboratory ${ }^{(1)}$. We analyze retrospectively the results of the routine intraoperative FS with the aim to evaluate its accuracy and sensitivity. We also evaluate the age of the patient and the tumor characteristics such as stage, histology, grade, and estrogen receptor (ER) in order to identify the predictive factors of lymph node metastasis.

\section{Patients and methods}

We analyzed the FS results from the Institute of Pathology and Cytopathology (São José do Rio Preto, São Paulo, Brazil). The results were reviewed and compared with the final pathology diagnosis and the statistical indices such as accuracy, sensitivity, specificity, and false results were calculated. The age of the patients and the stage, histology, grade and ER status of the tumors were obtained from medical records and organized in a database. The presence of lymph node metastases was analyzed in relation to each of these variables.

This study was approved by the Research Ethics Committee of the São José do Rio Preto Medical School (FAMERP - protocol 5726/2010).

\section{Statistical analyses}

The accuracy, sensitivity and specificity were calculated with the following standard formulas: accuracy $=$ (true positive + true negative)/(total number), sensitivity $=$ (true positive) $/$ (true positive + false negative) and specificity = (true negative)/(true negative + false positive).

Statistical analysis was performed using Pearson chi-squared test or Fisher Exact test (depending on the sample size) and Multivariate Logistic Regression. Statistical significance was denoted as $p>0.05$.

\section{Intra-operative assessment}

To FS the fresh lymph nodes were cut transversely into fragments of $2 \mathrm{~mm}$ thick. The tissue fragments were grouped and frozen in blocks. Subsequently, cryostat sections $(8 \mu \mathrm{m})$ were cut (Leica CM1100; Cryostat, Wetzlar, Germany) at three levels from each block and stained with Toluidine Blue dye. The remaining tissues were embedded in paraffin for postoperative analysis. Permanent sections of the positive and negative FS cases were stained with hematoxylin and eosin (H\&E) and were examined at an extra level. If no metastatic deposits were detected, three additional sections were obtained and analyzed by a combination of $\mathrm{H \& E}$ and immunohistochemistry (IHC). The first and last sections were $H \& E$ stained and the middle section was immunostained with pan-cytokeratin antibody (clone AE1/AE3, CellMarque, USA). Macrometastases were defined as a tumor deposit of more than $2 \mathrm{~mm}$ in size, micrometastases as a tumor deposit of 0.2 to $2 \mathrm{~mm}$ in size, and isolated tumor cells as single or clusters of tumor cells of less than $0.2 \mathrm{~mm}$ in aggregate size $^{(8)}$.

\section{Results}

A total of 177 results of the SLN intra-operative FS diagnosis were reviewed. The median age of the patients was 56 years with approximately two thirds (65\%) of them aged over 50 years. Most SLN specimens were from patients with invasive ductal carcinoma (77\%), with tumors $\leq 2 \mathrm{~cm}$ in size $(68 \%)$ and histologically graded as intermediate or high (82\%). The tumors' features are listed in Table 1.

The comparison between results of the FS diagnosis and final pathologic diagnosis on permanent sections are shown in Table 2. A total of 22 (12\%) metastases were found (13 macro and 9 micrometastases). All macrometastases and 1 micrometastases were detected by FS. An additional 8 micrometastases were detected in the postoperative analysis among the patients with negative FS, 5 in H\&E sections 


\begin{tabular}{|c|c|c|c|}
\hline Parameters & $n$ & $\begin{array}{l}\text { Positive } \\
\text { cases }\end{array}$ & $p$ value \\
\hline \multicolumn{4}{|c|}{ T stage } \\
\hline Tis & 22 & 0 & \multirow{7}{*}{$\begin{array}{l}p=0,7949 \\
\text { T1 vs. T2-T3 }\end{array}$} \\
\hline $\operatorname{T1mic}(\leq 0.1 \mathrm{~cm})$ & 5 & 1 & \\
\hline $\mathrm{T} 1 \mathrm{a}(>0.1-0.5 \mathrm{~cm})$ & 12 & 1 & \\
\hline $\mathrm{T} 1 \mathrm{~b}(>0.5-1 \mathrm{~cm})$ & 18 & 2 & \\
\hline T1c (> 1-2 cm) & 71 & 12 & \\
\hline T2 $(>2-5 \mathrm{~cm})$ & 33 & 4 & \\
\hline T3 $(>5 \mathrm{~cm})$ & 2 & 2 & \\
\hline \multicolumn{4}{|c|}{ Tumor histology } \\
\hline Invasive ductal & 136 & 19 & \multirow{4}{*}{$\begin{array}{l}\text { Invasive ductal } \\
\text { vs. invasive } \\
\text { lobular } \\
p=0,1641\end{array}$} \\
\hline Invasive lobular & 8 & 3 & \\
\hline $\begin{array}{l}\text { Ductal carcinoma } \\
\text { in situ }\end{array}$ & 22 & 0 & \\
\hline Others & 11 & 0 & \\
\hline \multicolumn{4}{|c|}{ Histological granding } \\
\hline G1 & 26 & 4 & \multirow{4}{*}{$\begin{array}{l}\text { G1 vs. G2-G3 } \\
p=0,7506\end{array}$} \\
\hline G2 & 58 & 6 & \\
\hline G3 & 63 & 9 & \\
\hline Note defined & 30 & 3 & \\
\hline \multicolumn{4}{|c|}{ Estrogen receptor status } \\
\hline Positive & 139 & 18 & Positive \\
\hline Negative & 24 & 2 & vs. negative \\
\hline Not determined & 14 & 2 & $p=0,7435$ \\
\hline
\end{tabular}

\section{Table 2 FS and postoperative diagnosis}

\begin{tabular}{|l|c|c|c|}
\hline \multicolumn{1}{|c|}{ FS } & Positive & Negative & Total \\
\hline Positive & 14 & 0 & 14 \\
\hline Negative & 8 & 155 & 163 \\
\hline Total & 22 & 155 & 177 \\
\hline
\end{tabular}

FS: Intraoperative frozen section analysis.

and 3 in $\mathrm{IHC}$ sections. The Figure shows a micrometastases detected in postoperative analysis by combined use of H\&E and IHC. No false positive case was observed. Based on these data, we calculated the statistical indices of $\mathrm{FS}$ (Table 3). High levels of accuracy and specificity were achieved at $95 \%$ and $100 \%$, respectively. The overall sensitivity of FS was $64 \%$. The sensitivity to detect macrometastases was $100 \%$, whereas the sensitivity for the detection of micrometastases was $11 \%$.

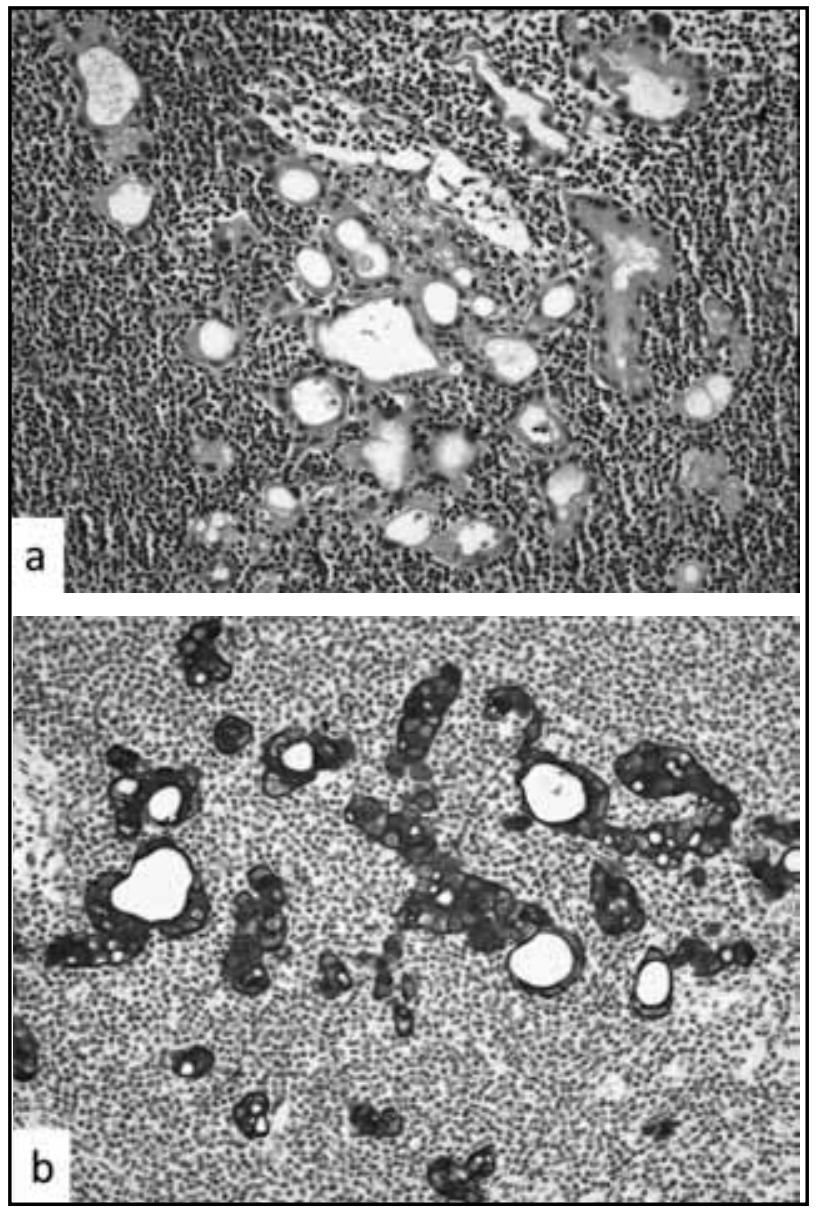

Figure - Sentinel lymph node with metastatic breast cells detected by a combination of $H \& E(a)$ and IHC (b)

H\&E: hematoxylin and eosin; IHC: immunohistochemistry.

\section{Table 3 Statistical scores of FS}

\begin{tabular}{|c|c|}
\hline Accuracy & $95 \%$ \\
\hline Sensitivity & $64 \%$ \\
\hline Specificity & $100 \%$ \\
\hline False-positive & $0 \%$ \\
\hline False-negative & $36 \%$ \\
\hline Predictive value of positive test & $100 \%$ \\
\hline Predictive value of negative test & $95 \%$ \\
\hline
\end{tabular}

FS: Intraoperative frozen section analysis.

The age of the patients and each of the characteristics of the tumor were compared between patients with and without metastasis using the Pearson chi-squared test and the Fisher Exact test, but no significant association with the presence of metastases was found $(p>0.05)$ (Table 1). The median age of the patients with (59 years) and without (56 years) metastasis was similar. The proportion of metastases was also comparable to tumors smaller and larger than $2 \mathrm{~cm}$ (T1 vs. T2-T3) as well as in tumors with different histology (invasive ductal vs. invasive lobular) 
or grade (low vs. intermediate and high grade). The occurrence of metastasis also was independent of the ER status. Analogous results were obtained in using Multivariate Logistic Regression (data not shown).

\section{Discussion}

The intraoperative frozen section diagnoses of SLN biopsy are performed to identify patients with positive nodes who may benefit from immediate axillary dissection. Therefore, FS must be very sensitive to detect metastases and specific to avoid an unnecessary ALND ${ }^{(5)}$. In this study, we retrospectively analyzed our results of the routine intra-operative FS with the aim to assess its accuracy and sensitivity.

In our cohort of 177 cases, FS data revealed 95\% accuracy, $64 \%$ sensitivity, and $100 \%$ specificity. Our results are in accord with previous studies, which report values of accuracy and sensitivity in the range of $84 \%-95 \%$ and $54 \%-94 \%$, respectively ${ }^{(12)}$. The accuracy and sensitivity values were affected by the suboptimal detection $36 \%$ of false negative results) of the micrometastases. Although all macrometastases were identified by FS diagnosis, only 1 of 9 micrometastases was detected. Several studies also show high accuracy for the detection of macrometastases, but were suboptimal in the detection of micrometastases ${ }^{(2,9,11)}$. FS revealed an overall sensitivity of $64 \%$, which reached $100 \%$ for macrometastases and $11 \%$ for micrometastases. Similar results (92\% and $17 \%)$ were related for Weiser et al. ${ }^{(19)}$ in 1000 consecutive breast cancer patients. The rate of micrometastases in false-negative cases was 100\%, which was higher than the $7 \%$ found among the true positive cases. There is a logical correlation between size of metastatic tumor deposit and the accuracy given the standard FS protocols $s^{(4,9,12,16)}$. In addition, all false-negative cases can be attributed to failure in sampling metastases smaller than $2 \mathrm{~mm}$ in size ${ }^{(19)}$.

The sensitivity is also tumor size dependent ${ }^{(13)}$. Therefore, the full examination by serial sectioning of the SLN would increase the sensitivity of FS diagnosis. Veronesi et al. ${ }^{(17)}$ reported an "exhaustive intraoperative frozen section method" of detection, which significantly improved on the false negative rate. Unfortunately, this may be impractical for application at most institutions $s^{(4,7)}$. In other words, a postoperative detailed analysis using serial or steps sectioning and IHC may increase the detection of metastatic cells and micrometastases and, may decrease the apparent sensitivity of intra-operative examination $^{(13,18)}$.

As in previous studies ${ }^{(7,14)}$, our results also show that the histopathologic detection of nodal micrometastases was further enhanced when $\mathrm{H} \& \mathrm{E}$ staining was supplemented by IHC staining using antibodies against cytokeratin. All SLN negative cases were finally analyzed by a combination of H\&E and immunohistochemistry in three additional levels. This approach increased the number of sections explored and incorporated the specificity and sensitivity of IHC. Three of the $8(37.5 \%)$ micrometastases found in post-operative analyses were identified in immunostained sections. These results have justified our routine use of $\mathrm{IHC}$ in postoperative analysis of the axillary sentinel lymph node.

Predictors of axillary lymph node metastases have been studied. One study showed that independent predictors of lymph node metastases in multivariate logistic regression analysis were tumor size and lymphovascular invasion ${ }^{(3)}$. Another study showed that tumor size, poor histologic grade, and younger age were associated with lymph node metastases ${ }^{(15)}$. Gadjos et al. found that lymphatic invasion, tumor size, and age were independently associated with lymph node metastases ${ }^{(6)}$. Additional studies also showed that lymphovascular invasion and tumor size were significantly associated with nodal metastases ${ }^{(10,20)}$. In our study, however, we did not find an association between lymph node metastases and age of the patients or the tumor primary characteristics. The proportion of lymph node metastases was comparable in relation to age of the patients and the stage, histology and grade as well as to ER status of the tumor. Thus, none of the characteristics analyzed proved to be a risk or protective factor to lymph node metastasis.

In conclusion, intraoperative FS is highly accurate and sensitive to detect macrometastases. However, it fails to identify micrometastases. The addition of the IHC in postoperative analysis improves the lymph node metastasis detection. The patient's age and stage, histology, grade and ER status of the tumor lack of the predictive value for lymph node metastasis.

\section{Acknowledgments}

This work was supported by the Institute of Pathology and Cytopathology (IAPC) and the Department of Pathology of the São José do Rio Preto Medical School (FAMERP) of the São José do Rio Preto, São Paulo, Brazil. 


\section{References}

1. AHMAD, Z. et al. Correlation of intra-operative frozen section consultation with the final diagnosis at a referral center in Karachi, Pakistan. Indian J Pathol Microbiol, v. 51, p. 469-73, 2008.

2. BROGI, E. et al. The results of frozen section, touch preparation, and cytological smear are comparable for intraoperative examination of sentinel lymph nodes: a study in 133 breast cancer patients. Ann Surg Oncol, v. 12, p. 173-80, 2005.

3. CHADHA, M. et al. Predictors of axillary lymph node metastases in patients with T1 breast cancer. A multivariate analysis. Cancer, v. 73, p. 350-3, 1994.

4. CHAO, C. et al. Utility of intraoperative frozen section analysis of sentinel lymph nodes in breast cancer. Am J Surg, v. 182, p. 609-15, 2001.

5. CIPOLLA, C. et al. The value of intraoperative frozen section examination of sentinel lymph nodes in surgical management of breast carcinoma. Langenbecks Arch Surg, 2009.

6. GAJDOS, C. et al. Lymphatic invasion, tumor size, and age are independent predictors of axillary lymph node metastases in women with T1 breast cancers. Ann Surg, v. 230, p. 692-6, 1999.

7. GIULIANO, A. E. et al. Improved axillary staging of breast cancer with sentinel lymphadenectomy. Ann Surg, v. 222, p. 394-9; discussion 399-401, 1995.

8. GOYAL, A. et al. Factors affecting failed localisation and false-negative rates of sentinelnode biopsy in breast cancer--results of the ALMANAC validation phase. Breast Cancer Res Treat, v. 99, p. 203-8, 2006.

9. GRABAU, D. A. et al. Intraoperative frozen section examination of axillary sentinel lymph nodes in breast cancer. Apmis, v. 113, p. 7-12, 2005.

10. HARDEN, S. P. et al. Predicting axillary lymph node metastases in patients with T1 Infiltrating ductal carcinoma of the breast. Breast, v. 10, p. 155-9, 2001.

11. KHALIFA, K. et al. The accuracy of intraoperative frozen section analysis of the sentinel lymph nodes during breast cancer surgery. Int J Fertil Womens Med, v. 49, p. 208-11, 2004.

12. LANGER, I. et al. Accuracy of frozen section of sentinel lymph nodes: a prospective analysis of 659 breast cancer patients of the Swiss multicenter study. Breast Cancer Res Treat, v. 113, p. 129-36, 2009.

13. LEUNG, K. M. et al. Clinical relevance of intra-operative sentinel lymph node examination in breast cancer management. Hong Kong Med J, v. 13, p. 8-11, 2007.

14. NOGUCHI, M. et al. Staging efficacy of breast cancer with sentinel lymphadenectomy. Breast Cancer Res Treat, v. 57, p. 221-9, 1999.

15. RIVADENEIRA, D. E. et al. Predictive factors associated with axillary lymph node Metastases in T1a and T1b breast carcinomas: analysis in more than 900 patients. $J$ Am Coll Surg, v. 191, p. 1-6; discussion 6-8, 2000.

16. TURNER, R. R. et al. Intraoperative examination of the sentinel lymph node for breast carcinoma staging. Am J Clin Pathol, v. 112, p. 627-34, 1999.

17. VERONESI, U. et al. Sentinel lymph node biopsy and axillary dissection in breast cancer: results in a large series. J Natl Cancer Inst, v. 91, p. 368-73, 1999.

18. WADA, N. et al. Evaluation of intraoperative frozen section diagnosis of sentinel lymph Nodes in breast cancer. Jpn J Clin Oncol, v. 34, p. 113-7, 2004.

19. WEISER, M. R. et al. Is routine intraoperative frozen-section examination of sentinel lymph nodes in breast cancer worthwhile? Ann Surg Oncol, v. 7, p. 651-5, 2000.

20. YIP, C. H. et al. Predictors of axillary lymph node metastases in breast cancer: is there a role for minimal axillary surgery? World J Surg, v. 33, p. 54-7, 2009.
Mailing address

Jorge Alberto Thomé

Rua XV de Novembro, 3.945

Redentora

CEP 15015-110 - São José do Rio Preto-SP

Tel.: (17) 3334-8888

e-mail: jathome@terra.com.br 